\title{
PEMBERDAYAAN SEBAGAI STRATEGI DALAM MENINGKATKAN \\ KESEJAHTERAAN MASYARAKAT DI KAWASAN PERBATASAN
}

Dr. Poppy Setiawati, S.Sos., M.Si

\begin{abstract}
Empowerment is a successful strategy to improve the welfare of people in the region. Because of the ability it has. This concept views the community as the subject of development, not as a result of development, so that people can enjoy the real development. The synergy between government, community and private parties in empowerment is an important aspect in improving the welfare of people in the region. In the perspective of the science of defense, empowerment is one of the state defenses in the region. This condition supports the realization of the screen as a unified, sovereign and secure, united front porch of the Unitary State of the Republic of Indonesia.
\end{abstract}

\section{Keyword : Empowerment, Community Welfare, Border Area.}

\section{Pendahuluan}

Pemerintah Indonesia menetapkan Rencana Pembangunan Jangka Panjang (RPJP) 2004-2025 sebagai salah satu arah kebijakan pembangunan yang memuat tujuan pembangunan, yaitu mewujudkan pembangunan yang merata dan dapat dinikmati seluruh komponen bangsa di berbagai wilayah Indonesia, termasuk perbatasan. Pada kenyataannya, saat ini masyarakat di kawasan perbatasan masih belum dapat menikmati hasil pembangunan. Kondisi ini menyebabkan masyarakat terperangkap dalam kemiskinan yang disebabkan adanya keterbatasan dalam mengakses sumber daya alam, sarana dan prasara, pendidikan, kesehatan, ekonomi, dan aspek kehidupan lainnya. Hal ini menunjukkan belum optimalnya pembangunan di kawasan perbatasan.

Sampai saat ini, kawasan perbatasan identik dengan daerah terisolir, terpencil, dan sulitnya koneksivitas dan aksesibilitas terhadap wilayah lain. Hal ini menimbulkan peluang kegiatan illegal, contohnya: pencurian kekayaan alam, perdagangan manusia, perdagangan narkoba, penyelundupan berbagai barang kebutuhan pokok, dan kegiatan illegal lainnya yang dapat merugikan masyarakat dan negara. Berdasarkan pada pengalaman penulis dalam mengkaji beberapa kawasan perbatasan, kondisi perbatasan yang jauh dari apa yang diharapankan masih terdapat di perbatasan, antara lain: Indoensia dan Malyasia yaitu di Pulau Sebatik (Kalimantan Utara), Krayan (Kalimantan 
Utara), Paloh (Kalimantan Barat), Kupang (NTT) dan Skow (Papua). Selain itu, sampai saat ini masih terdapat kawasan perbatasan yang jauh dari kata sejahtera untuk masyarakatnya. Apabila hal ini dibiarkan terus berlarut, maka akan berpotensi sebagai ancaman bagi kesejahteraan, kedaulatan dan keutuhan wilayah NKRI. Oleh karena itu, penting untuk mengkaji strategi yang dapat meningkatkan kesejahteraan masyarakat agar masyarakat dapat hidup dengan tentram dan damai di wilayah NKRI.

Dalam upaya membangun dan menjaga kedaulatan NKRI, Pemerintah Jokowi memiliki agenda prioritas yang dikenal dengan Nawacita. Salah satu agendanya fokus pada perbatasan, yaitu membangun dari pinggiran dengan memperkuat daerah-daerah dan desa-desa dalam kerangka negara kesatuan. Dengan demikian, untuk memperkuat kawasan perbatasan diperlukan suatu strategi yang tepat agar kesejahteraan masyarakat di kawasan perbatasan meningkat dan dapat terbebas dari belenggu kemiskinan.

Kemiskinan menyebabkan ketidakberdayaan masyarakat terhadap akses sumber daya. Dalam upaya meningkatkan kesejahteraan masyarakat di kawasan perbatasan, maka tulisan ini berusaha untuk mengkaji mengapa pemberdayaan merupakan aspek penting dalam meningkatkan kesejahteraan masyarakat sehingga permberdayaan merupakan strategi yang dianggap tepat dalam konteks pembangunan. Dengan menerapkan konsep ini di kawasan perbatasan diharapkan dapat mendukung terwujudnya perbatasan sebagai beranda Negara Kesatuan Indonesia (NKRI) yang berdaya saing, berdaulat dan aman.

\section{Pemberdayaan Masyarakat di Kawasan Perbatasan}

Pemberdayaan

(Empowement) merupakan salah satu paradigma pembangunan yang dilaksanakan dalam kegiatan pembangunan masyarakat, khususnya pada negara-negara yang sedang berkembang. Pemberdayaan masyarakat merupakan konsep yang muncul karena adanya asumsi terhadap kegagalan pembangunan yang cenderung bersifat sentralistis. Tujuan pemberdayaan masyarakat adalah memampukan dan memandirikan masyarakat terutama dari kemiskinan dan keterbelakangan/ kesenjangan/ ketidakberdayaan.

Pemberdayaan bukan hanya meliputi penguatan individu anggota masyarakat, tetapi juga pranata-pranatanya dengan cara menanamkan nilai-nilai budaya yang dapat meningkatkan kemampuan dan kemandirian, seperti kerja keras, hemat, keterbukaan, dan kebertanggungjawaban yang merupakan bagian pokok dari upaya pemberdayaan. 
Peningkatan kapasitas masyarakat dengan menggunakan pendekatan pembedayaan berkaitan dengan peningkatan partisipasi masyarakat dalam proses pengambilan keputusan. Oleh karena itu, pemberdayaan masyarakat amat erat kaitannya dengan partisipasi, pemantapan, pembudayaan, pengamalan demokrasi. Sebagaimana dijelaskan oleh Friedmann (1992) yang menawarkan konsep atau strategi pembangunan yang populer disebut dengan empowerment atau pemberdayaan. Konsep pemberdayaan ini adalah sebagai suatu konsep alternatif pembangunan yang pada intinya memberikan tekanan pada otonomi dalam mengambil keputusan di suatu kelompok masyarakat yang dilandaskan pada sumber daya pribadi, bersifat langsung, demokratis dan pembelajaran sosial melalui pengalaman langsung. Fokus utama pemberdayaan, menurut Friedmann, adalah sumber daya lokal, namun bukan berarti mengabaikan unsurunsur lain yang berada di luar kelompok masyarakat, bukan hanya ekonomi akan tetapi juga politik, agar masyarakat memiliki posisi tawar menawar yang seimbang, baik ditingkat lokal, nasional maupun internasional. Dalam konteks pemberdayaan masyarakat di kawasn perbatasan, konsep ini sejalan dengan kebijakan pemerintah yang menjadikan perbatasan sebagai beranda negara yang memiliki daya saing, berdaulat dan aman.
Program pemberdayan masyarakat merupakan program pembangunan berdasar partisipasi masyarakat (community based development). Pelaksanaan program diarahkan untuk melakukan pemberdayaan kepada masyarakat agar dapat meningkatkan kesejahteraan dan lingkungannya secara mandiri dan berkelanjutan (Suhartimi, dkk : 2005). Lebih lanjut, merujuk pada penjelasan Elliot (1987), dalam mengimplementasikan pemberdayaan sebagai suatu strategi meningkatkan kesejahteraan masyarakat, dapat dilakukan melalui tiga pendekatan yaitu: a). The Welfare Approach, b). The Development Approach, c) The Empowerment Approach. Masing-masing pendekatan memiliki fokus yang berbeda dalam upaya memberdayakan masyarakat. The Welfare Approach merupakan pendekatan yang mengarah pada pendekatan manusia, dan bukan untuk memberdayakan masyarakat dalam menghadapi proses politik dan pemiskinan rakyat. Oleh karena itu pendekatan ini menjadi sesuatu yang mutlak untuk mempermudah pembangunan kawasan secara umum. Lebih lanjut, The Development Approach; pendekatan ini bertujuan untuk mengembangkan proyek pembangunan untuk meningkatkan kemampuan, kemandirian dan keswadayaan masyarakat. Infrastruktur penunjang pembangunan 
merupakan instrument inti dalam pembangunan manusia secara umum. Pendekatan ini melihat pembangunan infrastruktur sebagai unsur pokok dalam menuju kemandirian masyarakat. Dan, The Empowerment Approach, merupakan pendekatan yang melihat bahwa kemiskinan sebagai akibat dari proses politik dan berusaha untuk memberdayakan atau melatih rakyat untuk menanggulangi ketidakberdayaan masyarakat. Masyarakat harus memiliki kemampuan untuk membangun diri sendiri tanpa menunggu dan tergantung dengan pihak lain.

Berdasarkan pada penjelasan Elliot, maka pendekatan yang dianggap relevan dalam meningkatkan kesejahteraan masyarakat di kawasan perbatasan, yaitu Empowerment Approach. Pendekatan ini melihat bahwa kemiskinan terjadi karena proses politik yang ditandai dengan terjadinya proses pembangunan yang tidak optimal sehingga pembangunan dianggap gagal dan membuat masyarakat tidak berdaya dalam mengakses sumber daya yang tersedia. Oleh karena itu, masyarakat harus diberdayakan agar memiliki kemampuan untuk membangun diri sendiri dan tidak tergantung pada pihak lain. Pemberdayaan sebagai suatu strategi yang dapat memampukan dan memandirikan masyarakat, merupakan upaya yang dapat dilakukan dalam meningkatkan kesejahteraan masyarakat di kawasan perbatasan.

Dalam konteks pembangunan masyarakat di kawasan perbatasan sebagai upaya dalam mendukung strategi pertahanan semesta, maka aspek penting yang harus diperhatikan, yaitu masyarakat sebagai subjek pembangunan. Masyarakat perbatasan identik dengan kemiskinan, SDM rendah, minim terhadap akses sumber daya serta sarana dan prasara umum, sehingga hal ini membuat masyarakat menjadi tidak berdaya. Jika masyarakat sebagai subjek pembangunan merupakan masyarakat dengan SDM yang rendah maka kondisi ini berpotensi sebagai ancaman terhadap pertahanan negara. Sebagai mana dijelaskan dalam UndangUndang Nomor 3 Tahun 2002 tentang Pertahanan Negara menyatakan bahwa sistem pertahanan negara bersifat semesta. Pernyataan ini bermakna dalam penyelenggaraan pertahanan negara melibatkan seluruh warga negara, wilayah, dan sumber daya nasional lainnya, serta dipersiapkan secara dini oleh Pemerintah dan diselenggarakan secara total, terpadu, terarah, dan berlanjut untuk menegakkan kedaulatan negara, keutuhan wilayah dan keselamatan segenap bangsa dari segala ancaman.

Konteks ancaman yang dimaksud dalam kajian ini merujuk pada penjelasan Buku Postur Pertahanan Negara (2014:39) 
bahwa ancaman pada hakekatnya secara sistematis dapat membahayakan kedaulatan negara, keutuhan wilayah NKRI, dan keselamatan segenap bangsa. Selanjutnya yang dimaksud dengan sumber daya nasional merupakan sumber daya manusia, sumber daya alam, dan sumber daya buatan. Sedangkan, sumber daya buatan adalah sumber daya alam yang ditingkatkan daya gunanya untuk kepentingan pertahanan negara. Dalam perspektif pertahanan negara, ancaman terdiri dari ancaman militer dan ancaman non militer. Ancaman militer merupakan ancaman yang berdimensi militer yang dapat membahayakan kedaulatan bangsa, keutuhan wilayah NKRI dan keselamatan segenap bangsa. Sedangkan, ancaman nonmiliter merupakan ancaman yang disebabkan faktor-faktor nonmiliter.

Ancaman nonmiliter dapat berasal dari luar negeri atau dapat pula bersumber dari dalam negeri. Ancaman nonmiliter digolongkan ke dalam ancaman yang berdimensi ideologi, politik, ekonomi, sosial budaya, keselamatan umum, teknologi, dan berdimensi legislasi (Postur Pertahanan Negara, 2014:46). Dengan demikian, dalam perspektif ilmu pertahanan, kondisi masyarakat di kawasan perbatasan dengan segala keterbatasannya berpotensi sebagai ancaman yang bersifat nonmiliter. Oleh karena itu, diperlukan suatu strategi untuk memberdayakan masyarakat agar masyarakat dapat menanggulangi ancaman non militer dengan segara kemampuan yang dimiliki dalam mendukung pertahanan negara. Kondisi masyarakat yang berdaya dapat dikatakan telah memiliki daya tangkal terhadap berbagai ancaman. Hal ini merupakan salah satu wujud bela negara. Sebagaimana dijelaskan oleh Tippe (2016) bahwa output yang dihasilkan dalam ilmu pertahanan yaitu tertanamnya kesadaran bela negara yang terdiri atas: cinta tanah air, kesadaran berbangsa dan bernegara, yakin akan Pancasila sebagai ideologi negara, rela berkorban, dan memiliki kemampuan awal bela negara.

Pertahanan negara diselenggarakan melalui membangun dan membina kemampuan, daya tangkal negara dan bangsa serta menanggulangi setiap ancaman. Pernyataan tersebut bermakna bahwa dalam menyelenggarakan pertahanan negara perlu membangun dan membina masyarakat secara terpadu, terarah dan berkelanjutan agar masyarakat menjadi berdaya dalam menanggulangi ancaman. Hal ini sejalan dengan konsep pemberdayaan yaitu meningkatkan kemampuan dan kemandirian masyarakat agar memiliki peluang dalam mengakses sumber daya dan tidak tergantung pada yang lain.

Saat ini, masyarakat di kawasan perbatasan diasumsikan belum memiliki 
kemampuan yang optimal karena masih terbelenggu dalam kemiskinan sehingga tingkat kesejahteraannya rendah. Dalam menanggulangi hal ini, konsep pemberdayaan dapat dijadikan sebagai strategi untuk meningkatkan kemampuan dan kemandirian masyarakat agar masyarakat menjadi berdaya. Dengan kata lain, pemberdayaan merupakan suatu strategi yang membantu masyarakat untuk mampu menolong dirinya sendiri. Pemberdayaan menciptakan peluang dan akses bagi masyarakat terhadap sumber daya dan memotivasi masyarakat untuk dapat menjadi mandiri.

Dalam melaksanakan pemberdayaan pada masyarakat kawasan di perbatasan perlu diperhatikan beberapa aspek berikut ini : bersifat bottom up, latar belakang budaya, profil masyarakat, jenis dan karakter perbatasan, keterlibatan seluruh pihak (masyarakat, Pemerintah dan pihak swasta), keberlanjutan, monitoring dan evaluasi. Lebih lanjut, Eko (2002) menyatakan bahwa proses pemberdayaan dapat berlangsung lebih kuat, komprehensif dan berkelanjutan apabila berbagai unsur terkait membangun kemitraan dan jaringan yang didasarkan pada prinsip saling percaya dan menghormati. Selain itu, menurut Chamber (1995), konsep pemberdayaan mencerminkan paradigma baru pembangunan, yakni yang bersifat "people centred, participatory, empowering, and sustainable”. Dengan demikian, tujuan pemberdayaan adalah memberikan ruang untuk menumbuhkan inisiatif, kreativitas dan jiwa kemandirian masyarakat, memampukan, dan membangun kemampuan usaha dalam meningkatkan kesejahteraan untuk memajukan diri ke arah kehidupan yang lebih baik secara berkesinambungan.

Dalam konteks perbatasan, pemberdayaan masyarakat dapat dilakukan dengan cara memberikan edukasi kepada masyarakat secara formal dan non formal dalam bentuk berbagai program pemberdayaan untuk memampukan dan memandirikan masyarakat sehingga masyarakat dapat menyadari pentingnya memiliki kemampuan dan kemandirian dalam mengakses sumber daya yang tersedia. Edukasi secara formal dapat dilakukan melalui pendidikan sejak dini dan secara informal dapat dilakukan melalui berbagai pertemuan dengan metode sosialisasi. Hal ini bertujuan untuk meningkatkan kesejahteraan masyarakat di kawasan perbatasan sehingga perbatasan dapat menjadi beranda depan NKRI yang berdaya saing, berdaulat dan aman.

\section{Kawasan Perbatasan sebagai Beranda Depan NKRI \\ Secara geografis, Indonesia} memiliki dua dimensi perbatasan yaitu 
kawasan perbatasan daratan dan kawasan perbatasan laut. Indonesia secara langsung berbatasan di wilayah perbatasan daratan dengan 3 (tiga) negara, yaitu : Malaysia, Papua Nugini dan Timor Leste. Di wilayah perbatasan laut, Indonesia berbatasan langsung dengan sepuluh negara, yaitu : Malaysia, Singapura, Filipina, India, Thailand, Vietnam, Republik Palau, Australia, Timor Leste dan Papua Nugini. Kawasan perbatasan darat di Indonesia terletak di 4 (empat) provinsi, yaitu Kalimantan Barat, Kalimantan Timur, Papua dan Nusa Tenggara Timur. Sedangkan, pada kawasan perbatasan laut, ada 6 (enam) provinsi yang memiliki perbatasan langsung dengan negara lain, yaitu Riau, Kalimantan Timur, Kalimantan Barat, Sulawesi Utara, Papua, dan Nusa Tenggara Timur, (Yasni, dalam Nurisnaeny, 2013).

Kawasan perbatasan memiliki nilai strategis dan peran penting terhadap kedaulatan, martabat dan harga diri sebuah Negara. Oleh karena itu, perbatasan menjadi penting dipertahankan dan dibangun karena terdapat banyak potensi keuntungan dan kerugian. Kawasan perbatasan (border areas) selalu dikaitkan dengan sebuah atau lebih wilayah yang secara geografis berhadapan langsung dengan wilayah (territory) negara asing atau negara tetangga. Berdasarkan Undang-Undang (UU) Nomor 43 Tahun
2008 tentang Wilayah Negara bahwa kawasan perbatasan adalah bagian dari wilayah negara yang terletak pada sisi dalam sepanjang batas wilayah Indonesia dengan negara lain. Dalam hal ini, batas wilayah negara di darat, kawasan perbatasan berada di kecamatan. Lebih lanjut, Kawasan Perbatasan Negara menurut UU Nomor 26 Tahun 2007 tentang Penataan Ruang, merupakan kawasan strategis yang dilihat dari sudut kepentingan pertahanan dan keamanan.

Kawasan perbatasan menurut Martinez (1994) dikategorikan ke dalam empat (4) tipe. Pertama; aliniated borderland, dalam kategori ini tidak terjadi aktivitas lintas batas sebagai akibat berkecamuknya perang, konflik kebencian idealogis, permusuhan agama, perbedaan kebudayaan dan persaingan etnis. Kedua; coexistent borderland, suatu kawasan perbatasan di mana konflik lintas batas dapat ditekan sampai ke tingkat yang dapat dikendalikan, meskipun masih muncul persoalan dalam kaitannya dengan kepemilikan sumber daya strategis di kawasan perbatasan. Ketiga; interdependent borderland merupakan tipe kawasan perbatasan dimana wilayah kedua sisi yang saling berbatasan menunjukkan gambaran stabilitas hubungan internasional antara kedua negara atau lebih yang saling berbatasan. Masyarakat di sepanjang kedua 
kawasan perbatasan terjalin hubungan yang saling menguntungkan secara ekonomi, seperti dalam penyediaan fasilitas produksi dan penyediaan tenaga kerja. Keempat; integrated borderland, yaitu kawasan perbatasan dimana kegiatan ekonomi merupakan sebuah kesatuan, nasionalisme jauh menyurut pada kedua negara dan kedua negara tergabung dalam sebuah persekutuan yang kuat. Hal ini tampak di kawasan perbatasan antara Amerika dan Kanada.

Merujuk pada penjelasan Martinez, maka sebagian besar tipe atau karakter kawasan perbatasan di Indonesia merupakan interdependent borderland. Dengan mengetahui karakter perbatasan maka diharapkan dapat menentukan program pemberdayaan yang relevan untuk meningkatkan kesejahteraan masyarakat di kawasan perbatasan. Pemberdayaan di kawasan perbatasan menjadi penting sebagai mana dijelaskan dalam UU Nomor 26 Tahun 2007 bahwa kawasan perbatasan merupakan kawasan strategis yang dilihat dari sudut kepentingan pertahanan dan keamanan. Dengan demikian, kawasan perbatasan memiliki arti penting dalam konteks pertahanan dan keamanan.

Saat ini, sebagian besar wilayah perbatasan di Indonesia masih merupakan daerah tertinggal dengan sarana dan prasarana sosial dan ekonomi yang masih sangat terbatas. Kondisi ini membuat masyarakat tidak berdaya sehingga kesejahteraan masyarakat di kawasan perbatasan rendah. Oleh karena itu, pemberdayaan masyarakat di kawasan perbatasan harus dilaksanakan karena perbatasan berkaitan dengan kedaulatan dan harga diri bangsa. Pemberdayaan masyarakat dengan tujuan mewujudkan paradigma perbatasan sebagai beranda NKRI melalui agenda Nawacita perlu dilakukan secara komprehensif, dalam arti tidak hanya melalui pendekatan kesejahteraan, akan tetapi juga dilakukan dengan pendekatan keamanan dan lingkungan. Dengan demikian, diperlukan keseriusan dan komitmen, baik pemerintah pusat maupun pemerintah daerah, masyarakat dan pihak swasta untuk menjadikan daerah perbatasan sebagai beranda depan bangsa yang memiliki daya saing, berdaulat dan aman. Dalam hal ini pemberdayaan masyarakat merupakan strategi yang dapat menjadi kunci sukses dalam pembangunan di kawasan perbatasan.

Meningkatkan kualitas sumberdaya manusia di kawasan perbatasan melalui pendekatan pemberdayaan merupakan suatu upaya pembangunan manusia agar masyarakat di kawasan perbatasan memiliki kemampuan dan kemandirian sehingga memiliki daya saing. Pembangunan di kawasan perbatasan harus dilakukan secara komprehensif dengan 
keterlibatan semua pihak, baik pemerintah maupun masyarakat yang dikuatkan oleh sektor swasta. Dengan pendekatan pemberdayaan diharapkan masyarakat memiliki peluang besar untuk dapat bertahan hidup dan menjadi garda terdepan bangsa yang memiliki daya saing untuk berkiprah di ajang nasional maupun internasional. Untuk mewujudkan itu semua perlu kerja keras dan kerja sama dari semua pihak agar terwujud sinergi.

Komitmen pemerintah dalam pembangunan kawasan perbatasan diharapkan dapat mempercepat berkembangnya kawasan perbatasan negara sesuai tujuan pembangunan, yaitu meningkatkan kesejahteraan masyarakat dalam mengejar ketertinggalan dari wilayah lain di sekitarnya yang lebih berkembang ataupun untuk menyelaraskan dengan perkembangan yang terjadi di negara tetangga. Upaya ini dilakukan agar masyarakat dan perbatasan memiliki daya saing, berdaulat dan aman.

\section{Penutup}

Pemberdayaan merupakan strategi yang sukses meningkatkan kesejahteraan masyarakat di kawasan perbatasan karena pemberdayaan bertujuan untuk meningkatkan kemampuan dan kemandirian masyarakat dalam mengatasai masalah yang dihadapi dengan kemampuan yang dimilikinya. Konsep ini memandang masyarakat sebagai subjek pembangunan, bukan sebagai objek pembangunan, sehingga masyarakat dapat menikmati hasil pembangunan secara nyata. Sinergi antara pemerintah, masyarakat dan pihak swasta dalam pemberdayaan merupakan aspek penting dalam meningkatkan kesejahteraan masyarakat di kawasan perbatasan. Dalam perspektif ilmu pertahanan, pemberdayaan merupakan salah satu wujud bela negara di kawasan perbatasan. Kondisi ini mendukung terwujudnya perbatasan sebagai beranda depan NKRI yang berdaya saing, berdaulat dan aman.

Dalam proses pemberdayaan untuk meningkatkan kesejahteraan masyarakat di kawasan perbatasan, perlu diperhatikan beberapa hal berikut ini, yaitu :

1. Perlu meningkatkan koordinasi berbagai pihak yang terlibat dalam proses pembangunan kawasan perbatasan

2. Pemerintah perlu mendengarkan aspirasi masyarakat dalam membangun kawasan perbatasan agar pembangunan tepat sasaran dan tujuan meningkatkan kesejahteraan masyarakat dapat tercapai

3. Perlu menyadari pentingnya keberdayaan masyarakat dalam upaya meningkatkan kesejahteraan masyarakat agar terwujud 
pertahanan negara di kawasan perbatasan.

4. Perlu menerapkan monitoring dan evaluasi, menempatkan masyarakat sebagai subjek dan mengimplementasikan program pemberdayaan masyarakat secara berkelanjutan agar masyarakat dapat menikmati hasil pembangunan secara nyata.

\section{Referensi}

Buku Putih Pertahanan Republik Indonesia. 2014. Kementerian Pertahanan Republik Indonesia.

Buku Postur Perahanan Republik Indonesia. 2014. Kementerian Pertahanan Republik Indonesia.

Chambers, R. 1985. Rural Development : Putting The Last First. London ; New York: Longman.

Heni. "Isu-isu Strategis Perbatasan Negara Perspektif BNPP”. Diakses melalui http://bnpp.go.id/index.php/pojokbnpp/375-isu-isu-strategisperbatasan-negara-perspektifbadan-nasional-pengelolaperbatasan, 10 November 2016.

Martinez, Oscar, J. 1994. Border People. Tucson:University of Arizona Press.

Nurisnaeny, Poppy Setiawati. 2013. "Adaptasi Nelayan di Kawasan Perbatasan”. Disertasi Bidang Ilmu Sosial. Universitas Padjadjaran

Rr. Suhartini A, Halim Imam, Khambali, dan Abd Basyd (eds). 2005. Model-
Model Pemberdayaan Masyarakat. Yogyakarta : Pustaka Pesantren.

Sunyoto Usman. 2004. Pembangunan dan Pemberdayaan Masyarakat., Yogyakarta : Pustaka Pelajar.

Sutoro, Eko. 2002. "Pemberdayaan Masyarakat Desa”. Materi Diklat Pemberdayaan Masyarakat Desa. Samarinda : Badan Diklat Provinsi Kaltim.

Tippe, Sarifudin. 2016. Ilmu Pertahanan : Sejarah : Konsep dan Implementasi. Jakarta : Salemba Humanika.

Undang-Undang RI Nomor 3 Tahun 2002 tentang Pertahanan Negara

Undang-Undang RI Nomor 26 Tahun 2007 tentang Penataan Ruang 